\title{
Diagnóstico técnico preliminar da Ruína da Igreja Matriz de Vila Bela da Santíssima Trindade-MT e entorno
}

\section{Preliminary technical diagnosis of the Ruin of the Igreja Matriz in Vila Bela da Santíssima Trindade-MT and surroundings}

${ }^{1}$ Luciana Pelaes Mascaro

1Professora Dra. do Depto. de Arquitetura e Urbanismo, FAET-UFMT - mascaro.luciana@ gmail.com

\begin{abstract}
RESUMO: A cidade de Vila Bela da Santíssima Trindade localizada no Estado de Mato Gross tem um centro antigo com importante valor histórico, tombado na esfera estadual e ainda dois prédios tombados pelo IPHAN Instituto de Patrimônio Histórico Artístico Nacional, em esfera Federal. Um deles é a ruína da Igreja Matriz, que tem apresentado degradações devido a fatores variados. Em vista ao valor desse bem para o patrimônio histórico nacional, foi realização do diagnóstico técnico preliminar da ruína para identificar problemas e propor recomendações a fim de evitar a degradação do bem. Assim, objetivo deste artigo visa apresentar propostas de intervenções com intuito de resguardar esse patrimônio histórico para as futuras gerações. A ação se desenvolveu por meio de Projeto de Extensão universitária intitulada "Ações relacionadas à Preservação do Patrimônio Material e Ambiental em Mato Grosso", com isso foram identificados problemas e degradações ao bem cultural protegido e seu entorno, a partir da qual foram realizadas recomendações e propostas para a melhoria das condições do bem. As principais causas de degradação estão ligadas a conflitos humanos, má utilização, falta de drenagem e iluminação adequadas, intervenções equivocadas e, principalmente, a existência de uma colônia de pombos que se instalou na ruína, ao abrigo de sua cobertura. Como se trata de local e bem especiais, protegidos por tombamentos, as recomendações e as propostas de intervenções foram elaboradas seguindo as normas exigidas a respeito. Em fase a rápida degradação do bem, recomenda-se que as ações propostas sejam implementadas com maior rapidez possível para resguardar o patrimônio histórico local.
\end{abstract}

Palavras-chave: Ruína. Diagnóstico. Vila Bela da Santíssima Trindade.

\begin{abstract}
The city of Vila Bela da Santíssima Trindade, located in the State of Mato Gross, has an old center with important historical value, listed at the state level and also two buildings listed by IPHAN - National Artistic Heritage Institute, at the Federal level. One of them is the ruin of the Igreja Matriz, which has been degraded due to various factors. In view of the value of this property for the national historical heritage, a preliminary technical diagnosis of the ruin was carried out to identify problems and propose recommendations in order to avoid the property's degradation. Thus, the aim of this article is to present proposals for interventions in order to protect this historical heritage for future generations. The action was developed through the University Extension Project entitled "Actions related to the Preservation of the Material and Environmental Heritage in Mato Grosso", with this, problems and degradations to the protected cultural property and its surroundings were identified, from which recommendations were made and proposals for improving the conditions of the property. The main causes of degradation are linked to human conflicts, misuse, lack of adequate drainage and lighting, wrong interventions and, above all, the existence of a colony of pigeons that settled in the ruin, when As it is a special place and property, protected by tombstones, the recommendations and proposals for interventions were prepared following the standards required in this regard. In a phase of rapid degradation of the property, it is recommended that the proposed actions be implemented as quickly as possible to safeguard the local historical heritage.
\end{abstract}

Keywords: Ruins. Diagnosis. Vila Bela da Santíssima Trindade.

\section{INTRODUÇÃO}

As ruínas da Matriz de Vila Bela da Santíssima Trindade é patrimônio histórico tombado em nível nacional nos termos do Decreto-Lei ${ }^{\circ}$ 25/1937, inscrito no livro do Tombo Histórico, Volume II, em 13 de junho de 1988, conforme Processo $\mathrm{n}^{\circ}$ 877-T-1973 e ato publicado no D.O.U. em 03 de novembro de 1987.

O bem está protegido também, em nível estadual, pela Portaria ${ }^{\circ} 26 / 1984$ publicada no Diário Oficial do Estado de Mato Grosso, que tomba como Patrimônio Histórico e 
Artístico do Estado de Mato Grosso o perímetro urbano da cidade e todos os imóveis nele inseridos. Mais tarde, em 10/09/2002, o perímetro urbano foi delimitado de acordo com o parecer que "recomenda a delimitação do perímetro histórico de Vila Bela, para a preservação, o traçado original de 1773, cuja planta se encontra no Museu da Casa Ínsula, em Portugal" (SECRETARIA, 1984).

Além do reconhecimento pelos órgãos de preservação institucionais, o território de Vila Bela da Santíssima Trindade, bem como os remanescentes materiais históricos, tem o reconhecimento por parte da população da cidade, das comunidades rurais e quilombos da região. Em palavras mais contundentes, os aspectos material e imaterial do patrimônio vilabelense são parte da mesma manifestação identitária, cujo sentido remonta aos primeiros assentamentos mineradores da região, no início do século XVIII.

Devido às especificidades históricas locais, o território que abrange a cidade de Vila Bela, arraiais e quilombos é percebido como "espaço de liberdade", como descreveu Maria, em 24 de março de 2021. É necessário lembrar, conforme registrado na instrução do processo de tombamento do "Complexo Arqueológico Histórico Arraial de São Francisco Xavier" (MIGLIACIO, 2011, p. 56), que a formação dos vários quilombos da região, com destaque para aquele comandado por Teresa de Benguella,

\begin{abstract}
"plantaram as condições necessárias para que a população negra constituísse organização social e econômica próprias, independente do mando dos brancos, o que lhe permitiria continuar na região, a despeito de todas as condições adversas que teriam motivado a debandada da elite branca".
\end{abstract}

Além disso, "outro dado importante é fornecido também pelo próprio Rolim de Moura, sobre a utilização extensiva da mão de obra de negros livres na construção de Vila Bela" (MIGLIACIO, 2011, p. 56), o que reforça o sentido de liberdade acima citado.

É preciso ainda considerar a presença indígena nesse amplo território. O nativo participou do cotidiano e esteve inserido, tanto na organização social independente, quanto naquela sob o comando dos brancos, conforme registra Migliacio (2011, p. 58).

Soma-se a esse contexto, para reforçar o sentido de liberdade presente na história e na memória local, o fato de que população negra e nativa estiveram afastadas do comando do branco durante um período de mais de 130 anos. Como é sabido, esse intervalo é marcado pela transferência da capital de estado de Vila Bela para Cuiabá, em 1835 - quando os brancos abandonam a cidade - e o ano de 1977, quando novamente os interesses se voltam para a região, com a divisão do estado em Mato Grosso e Mato Grosso do Sul.

Isto posto, cabem as perguntas: a) como foram recebidos pela população local os atos de tombamento estadual e federal, em 1984 e 1987, respectivamente? b) qual foi o impacto dos atos de tombamento no cotidiano local?

Se faz necessário lembrar que o processo de tombamento federal foi motivado, em 1973, pela solicitação de reconhecimento das "construções que lembram e guardam os trabalhos dos Capitães-gerais que governaram Mato Grosso”, como atesta a indicação da Câmara de Cáceres protocolizado junto ao Iphan na ocasião. Ou seja, o entendimento sobre a proteção da memória estava voltado aos feitos do branco, em detrimento de outros. Não significa que o tombamento tenha sido equivocado. Significa, outrossim, que os objetos sob proteção institucional são repositórios de identidades passíveis de interpretação por diferentes grupos identitários. Dessa forma, outras questões que se colocam são: c) se continua a entender que os vestígios materiais ainda presentes em Vila Bela representam apenas os feitos dos brancos, como se entendia na década de 1970, ou representam também a memória da população afroindígena local? d) como a memória e tradição desses sujeitos da história estão contemplados nos tombamentos? 
Nesse ponto, é necessário abordar a questão da educação patrimonial - ou antes, da educação apenas. Além da educação que objetiva dar às crianças ferramentas para bem interpretar o mundo que a envolve e, por consequência, preservá-lo nas suas variadas dimensões, é preciso atingir outros grupos. Uma educação voltada aos representantes das instituições públicas e órgãos de preservação do patrimônio deve ser considerada e conduzida no sentido de ouvir, compreender e efetivar os anseios da população afroindígena local.

Tal ação poderia evitar equívocos por parte dos órgãos de preservação e resistências causadas por ruídos de comunicação, como os relatados por Maria em 24 de março de 2021. Ela relata que, quando Vila Bela foi abandonada, "os que ficaram é que tocaram tudo" e se perguntam o porquê, agora, os órgãos de preservação impedem que eles façam intervenções nas edificações. Ela continua explicando que, "quando os mais jovens deixam de intervir numa casa e ela cai, para os antigos é como se os jovens não tivessem tomado providências, mas os jovens não podem fazer nada sem autorização". Quando lhe foi perguntado como a população reagiria ao fechamento das ruínas, a entrevistada reage respondendo que

\footnotetext{
"vai ser um problema o controle de acesso ou o impedimento de acesso às ruínas, principalmente para os mais antigos (...) para os mais velhos esse território e os espaços são tidos como espaços de liberdade (...)é muito ruim, alguém que não tem nada a ver com a gente, chega, faz a intervenção e depois quer regular a nossa memória, a nossa identidade, controlar o acesso disso".
}

A própria entrevistada menciona que a educação patrimonial pode ajudar nesses conflitos e ajudaria a colocar o principal grupo interessado como protagonista de sua cultura e agente de preservação de seu patrimônio cultural. Pelo exposto, se percebe que é latente a percepção, por parte da população afroindígena local, de que ela é a sujeito do processo histórico e cultural que se desenrolou, e se desenrola, no território e não aceita ser ignorada nas decisões institucionais. Portanto, decisões que envolvem a preservação do patrimônio cultural devem contemplar os anseios dessa população, evitando ações que a desuna dos seus bens significativos, nomeadamente, controle ou proibição de acesso aos territórios e edificações tombados.

A ruína da Igreja Matriz e seu entorno tem apresentado degradações devido a fatores variados. Diante desse cenário, em vista ao valor desse bem para o patrimônio histórico nacional, objetivou-se nesse trabalho realizar um diagnóstico técnico preliminar dessa importante ruína com vistas a identificar problemas e propor recomendações a fim de evitar que a degradação destrua ainda mais esse bem tombado. Como específico, apresenta-se uma metodologia voltada para a realização de diagnóstico técnico voltado para bens tombados, com intuito de orientar futuros trabalhos a cerca do tema, especialmente a aqueles que almejem subsidiar decisões de ações civis publicas. O trabalho se desenvolveu por meio de Projeto de Extensão universitária intitulada "Ações relacionadas à Preservação do Patrimônio Material e Ambiental em Mato Grosso".

\subsection{Aspectos Físicos da Ruína da Igreja Matriz}

Consta no Processo de Tombamento Estadual, pasta 3, que "em 1769 já estava pronto o projeto da Matriz, mas foi apenas em 1771, que sua construção foi iniciada durante o governo de Luiz Pinto Souza Coutinho” (FINAGEIV, 1984, p.3). No mesmo documento há informação de que a edificação sofreu dois desabamentos, tendo sido reconstruída nos anos de 1775 e 1793. Depois, "a única informação segura, (...) é que, na ocasião da passagem da Expedição Rondon, a Matriz ainda estava de pé” (FINAGEIV, 1984, p.6)., na primeira década do século XX (VITAL, HOCHMAN, 2013). 
Ainda segundo descrição encontrada no documento "Obras de emergência..." (FINAGEIV, 1984), de setembro de 1984, trata-se das ruínas de uma edificação de grandes dimensões se comparada aos prédios da cidade, tendo $57,5 \mathrm{~m}$ de comprimento por $27,5 \mathrm{~m}$ de largura, e com paredes que podem atingir mais de $10 \mathrm{~m}$ de altura. Se constitui de um "embasamento de pedra canga talhada, com cunhais com perfil típico formado pela base, toro e plinto" e que chegam a 1,50m de altura. Sobre esse alicerce alto, se apoiam as paredes de adobe, que chegam a 1,80m de espessura, que foram preservadas das cheias do rio Guaporé por estarem distantes do chão (FINAGEIV, 1984, p.6). Trata-se, portanto, de uma ruína de terra crua, vulnerável à ação da água.

\subsection{Aspectos Teóricos do Patrimônio em Ruínas}

Em se tratando de bem tombado, ao qual valores culturais estão associados, todas as intervenções que nele venham a ser feitas devem ser realizadas de forma criteriosa, visto a responsabilidade que temos de transmitir para o futuro tanto o artefato material quanto seu significado, que não devem ser descaracterizados e/ou deturpados por intervenções inapropriadas e inconscientes. Essa diretriz está assentada, desde o século XIX, nos pensamentos de especialistas - tais como John Ruskin, Camilo Boito, Alois Riegl, Gustavo Giovannoni, Cesare Brandi dentre outros - que contribuíram com a Teoria da Conservação e do Restauro, reconhecida e adotada pelas principais instituições de salvaguarda do patrimônio cultural, como a UNESCO e o Iphan. Assim, qualquer intervenção no bem - ainda que de conservação, manutenção e limpeza - deve ser afastada de arbitrariedades, pela consideração de preceitos da Teoria da Conservação e do Restauro e outros documentos a ela ligados, como as cartas patrimoniais, documentos gerados pelo Iphan e documentos reconhecidos pela UNESCO. Portanto, o diagnóstico aqui apresentado, bem como as recomendações nele contidas, foi orientado pelos critérios teóricos citados.

Além disso, visto que existe a reponsabilidade de transmitir o bem e seus valores para as gerações futuras, qualquer tipo de abandono, negligência ou falta de manutenção que cause a degradação do bem, também é de nossa responsabilidade. Se impõem, então, a reflexão feita por Rodrigues (2013, p. 22): o que evoca atualmente o conjunto da ruína e sua cobertura, supostamente de proteção? "Um passado distante consumido pelas marcas do tempo ou um recente histórico de abandono?".

\section{MATERIAIS E MÉTODOS}

Este trabalho surge diante da necessidade de elaboração de um diagnóstico técnico preliminar para atendimento às deliberações interpostas pela Ação Civil Pública do Ministério Público Federal. O diagnóstico se desenvolve a partir do Projeto de Extensão intitulado "Ações relacionadas à Preservação do Patrimônio Material e Ambiental em Mato Grosso". Em decorrência do agravamento da pandemia de covid-19, não foi possível realizar estudos e levantamentos in loco. Assim, diante das adversidades impostas, buscou-se uma metodologia alternativa para elaborar o diagnóstico que envolve o bem protegido por tombamento a partir de registros do estado de conservação da ruína da Igreja Matriz de Vila Bela e de seu entorno utilizando-se fontes de informações secundárias já disponíveis sobre a obra em tela.

A pesquisa contou com a colaboração de alunos, que foram organizados de acordo com as etapas a serem realizadas, sendo que quatro trabalharam nos mapas de identificação do traçado urbano e do perímetro de tombamento estadual, de uso e ocupação do solo urbano e de conflitos e possibilidades e usos; e, três trabalharam com questionários. O levantamento dos dados para a elaboração do diagnóstico preliminar foi adaptado em decorrência do agravamento da pandemia de covid-19. De início, estavam previstos (i) estudos do perímetro de tombamento estadual para diagnóstico usos do solo, paisagem e relações entre edificações 
e (ii) levantamentos métricos e fotográficos dos prédios do Palácio dos Capitães Generais e da Ruína da Igreja Matriz para realização dos mapas de danos das edificações. Assim, o item (i) foi adaptado e realizado à distância e o item (ii), que se constituem de análises e levantamentos que exigiam a presença da equipe in loco, foi adaptado para garantir a segurança dos estudantes envolvidos no levantamento. Todavia, não houve prejuízo uma vez que o diagnóstico preliminar da Ruína da Igreja Matriz foi realizado a partir de fontes secundárias. Nesse sentido, o diagnóstico aqui apresentado foca nos problemas de degradação desse prédio e sua inserção no contexto urbano e paisagístico. seguintes:

As fontes secundárias que subsidiaram o levantamento de informações foram as

- Vídeos de Vila Bela da Santíssima Trindade, disponíveis no YouTube e realizados por moradores da cidade sob solicitação especialmente para este trabalho;

- Fotografias tiradas por moradores da cidade e de arquivos diversos;

- Análises de imagens por meio da ferramenta Google Maps;

- Questionários online com 29 pessoas, moradores e pessoas da cidade;

- Referências bibliográficas e documentais (Processo de Tombamento Estadual).

A demanda a este trabalho foi feita em razão de danos e degradações que atingem diretamente os prédios tombados da cidade, porém foi necessário compreendê-los e analisálos no âmbito do seu contexto, pois os problemas atingem o entorno da edificação e estão relacionados não apenas aos prédios, mas aos tipos de usos que estão sendo feitos dessa área. Não se trata simplesmente da conservação do aspecto material de bens culturais, mas da relação da sociedade com esses bens no presente. Qualquer intervenção nos bens pode beneficiar ou arruinar a relação das pessoas com os mesmos.

Dessa forma, o questionário online foi elaborado para a coleta de informação mais amplas, que dizem respeito à relação da população com determinados prédios e com o espaço urbano central, onde acontecem celebrações culturais. A identidade das pessoas que responderam ao questionário foi ocultada para protegê-las e, em especial, o nome de uma delas foi substituído, neste trabalho, pelo nome Maria. As questões respondidas foram organizadas em blocos, com os objetivos de:

- Identificar idade e sexo da pessoa;

- Compreender como se dá o uso do espaço quando acontecem festas (Você participa da Festa do congo? Qual o trajeto percorrido pela festa? A festa acontece na ruína? Onde acontece a distribuição de comida? A festa passa ou acontece no Palácio dos Capitães Generais?)

- Compreender quais necessidades, em termos de espaço construído, existem para abrigar práticas culturais (Você conhece o projeto do Congódromo, edificação que abrigaria a Festa do Congo e outras festas? É importante que ele seja construído? As festas precisam de banheiros, salão coberto, palco e cozinha?)

- Compreender aspectos ligados especificamente à ruína da Igreja Matriz e outras edificações históricas (Se o acesso à ruína fosse fechado, qual seria a reação da população? $\mathrm{O}$ que você acha da cobertura que protege atualmente a ruína? Existem outros edifícios importantes na cidade?)

Além disso, foi definida uma área para a análise, que compreende os prédios em questão: o perímetro de tombamento estadual, conforme Figura 1. 
Figura 1 - Vila Bela da Santíssima Trindade, perímetro de tombamento definido pelo Estado de Mato Grosso. 1) Ruína da Igreja Matriz - 2) Palácio dos Capitães Generais.

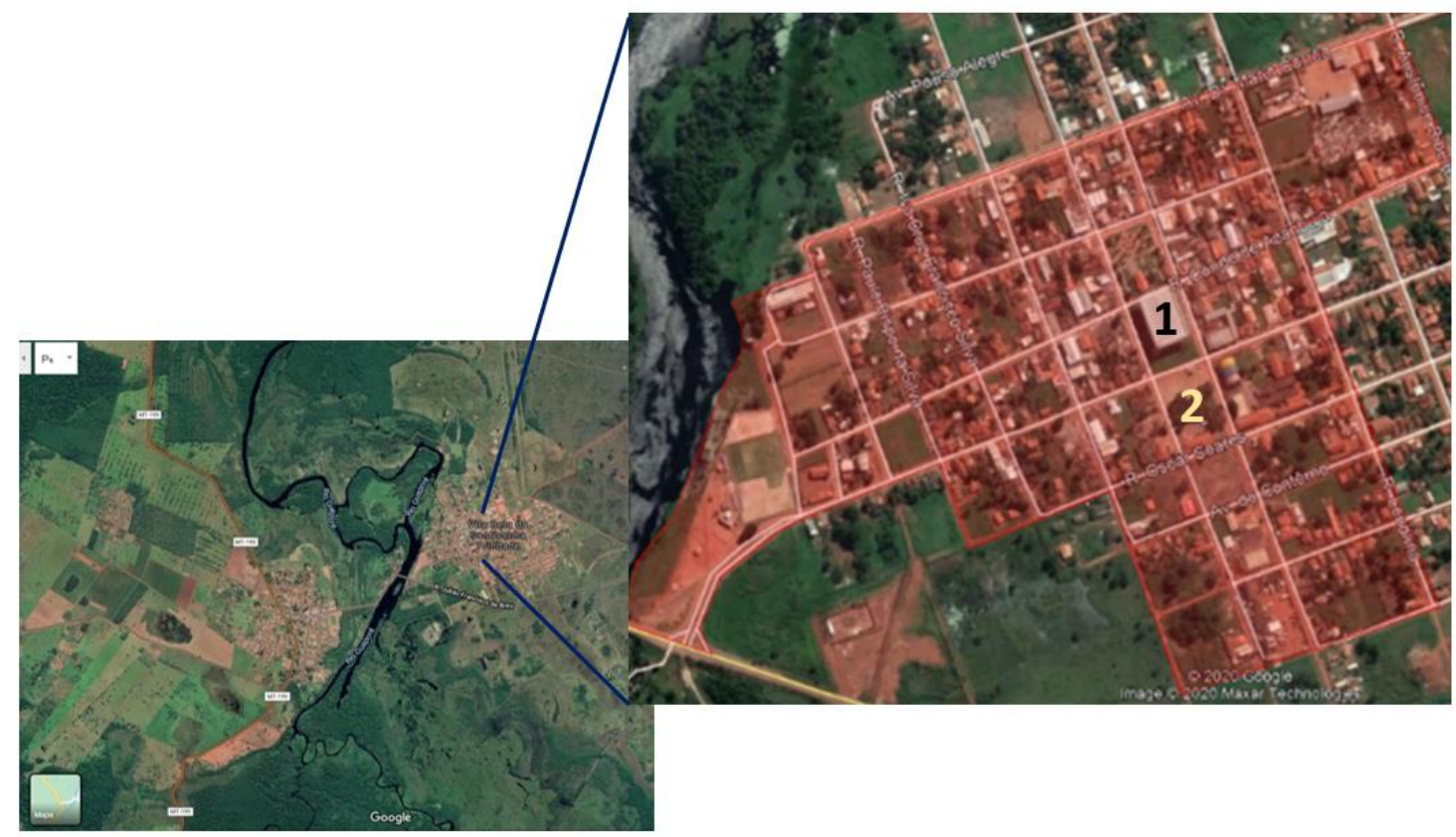

Fonte: Google Maps / Secretaria de Estado de Cultura, Esportes e Lazer (SECEL-MT).

Com as informações coletadas, foram realizadas uma análise diagnóstica e, posteriormente, foram sugeridas recomendações e propostas para a minimização e/ou resolução dos problemas encontrados na região central da cidade de Vila Bela. O diagnóstico procurou identificar a origem das causas, fossem elas intrínsecas ou extrínsecas. No caso, muitas das causas foram desencadeadas por falhas humanas ou mesmo por propostas inadequadas de intervenções. Há ainda aquelas decorrentes de causas naturais uma vez que o bem é um patrimônio de antiga data. Inicialmente, as causas são descritas e posteriormente organizadas em um quadro, onde constam as propostas de intervenções recomendadas.

\section{RESULTADOS/ DISCUSSÕES}

\subsection{Problemas e Deteriorações Identificadas}

Segundo relatos, questionários, vídeos e fontes de documentação que utilizamos as quais os autores tiveram acesso, os problemas identificados nas imediações e na própria Ruína da Igreja Matriz são relacionados:

I) A cobertura de proteção da ruína (presença de uma vasta colônia de pombos; drenagem do solo; má utilização e outros aspectos);

II) A falta de entendimento mútuo população/órgãos de preservação do patrimônio (conflitos humanos).

\subsection{Causas dos Problemas e das Deteriorações}

\subsubsection{Causas Humanas}

\section{a) Fata de Manutenção}

COBERTURA METÁLICA DA RUÍNA: Segundo Facchinetto (2006, p.4), em 02 de maio de 2006, "foi inaugurada uma cobertura de estrutura metálica e proteção em policarbonato" a fim de proteger as ruínas "da ação do tempo e dos vândalos" (Facchinetto, 
2013, p.4). Uma reportagem produzida pelo Jornal Oeste (2011, n.p.) informa sobre a cobertura metálica da ruína:

"A cobertura de proteção metálica das ruínas da Igreja Matriz de Vila Bela da Santíssima Trindade está se deteriorando", que "a administração municipal ficou de substituir telhas que voaram com um vendaval no início do ano" e que "o secretário de Cultura, [...], reconhece o problema e diz que ocorre desde 2008 (...) Mas, é uma ou outra telha, não é o telhado completo".

Na mesma reportagem, o então superintendente regional do Iphan à aquela época, informou em entrevista que "o telhado em material transparente é considerado provisório até que se ache uma solução mais adequada. Desde a sua instalação vem sendo discutida uma alternativa de proteção diferente". A entrevista segue declarando que havia dificuldades em contactar a empresa que construiu a cobertura. De onde se conclui que, apenas 2 anos após a inauguração da cobertura, começaram os problemas das telhas translúcidas da cobertura. Foi verificado, em maio de 2014, que o estado de conservação da cobertura das ruínas era delicado. Como se constata pelas fotos, várias telhas translúcidas da cobertura estavam quebradas, mal fixadas e com risco de desprender-se da estrutura.

AÇÃO DE AGENTE BIOLÓGICOS: colônia de Columba livia, pombos domésticos: Após 2016, não foi possível identificar quais medidas foram tomadas pelos entes responsáveis pela conservação da ruína para controlar e/ou eliminar a população de pombos. Também não foi possível identificar se foram tomadas medidas de limpeza no sentido de livrar a ruína e suas imediações dos ninhos e das fezes dos pombos.

ILUMINAÇÃO PÚBLICA: A falta de iluminação pública contribui com a degradação, pois o ambiente mal iluminado favorece o mau uso do espaço. Segundo o Secretário Municipal de Cultura, há um bom tempo que a rede de iluminação das ruínas não funciona. A rede "tem quedas de energia intermitente e será preciso uma rede nova com avaliação da capacidade de funcionamento”. Apesar disso, ainda segundo o secretário, a iluminação da ruína foi reativada no mês de março de 2021 (Figura 2).

Figura 2 - Iluminação da ruína da Igreja Matriz de Vila Bela.

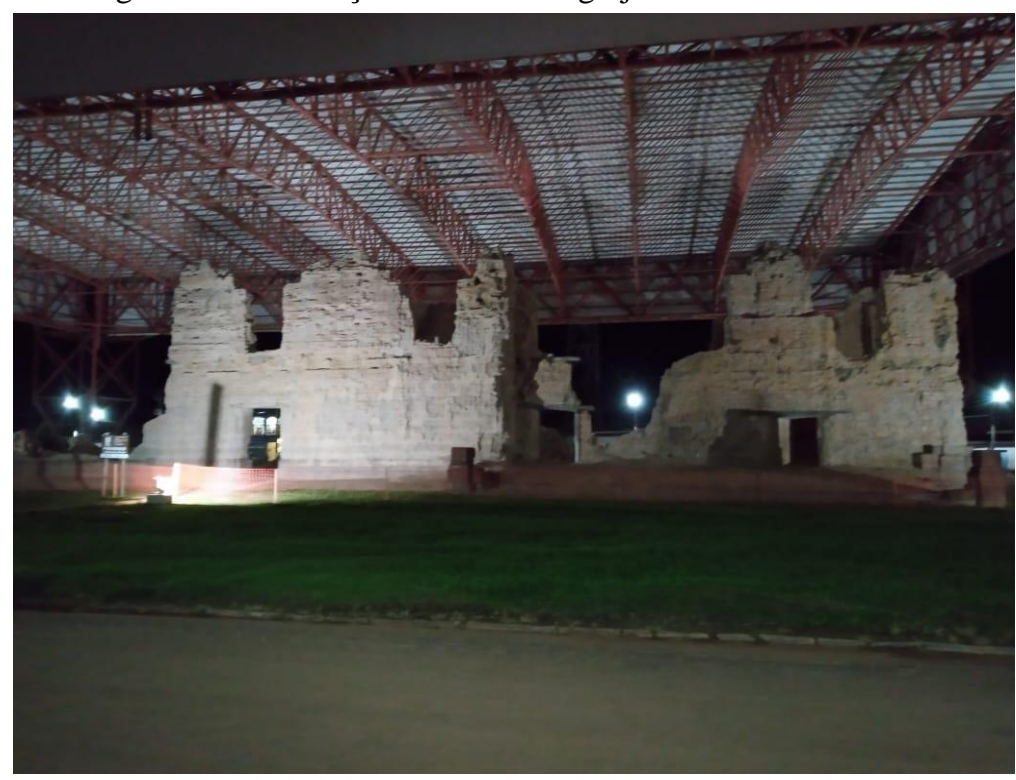

Fonte: Ednardo Marques de Almeida, março/2021. 


\section{b) Intervenções inadequadas}

COBERTURA DA RUÍNA: Em 2016, as telhas translúcidas foram trocadas por telhas opacas. Com recursos da Secretaria de Estado de Infraestrutura e Logística (SINFRA), foi realizada a obra de "recuperação da cobertura das ruínas da Igreja Matriz de Vila Bela da Santíssima Trindade-MT" (informações obtidas junto à Prefeitura do município). No projeto de troca das telhas apresentado pela Secretaria de Cultura do Estado de Mato Grosso, em 09/07/2015, ao Iphan-MT não há explicações sobre os motivos da substituição das telhas translúcidas por opacas; apenas uma observação sobre a necessidade de emprego de "material mais resistente". Relatos de moradores informam que, por volta de um ano após a instalação das telhas opacas, em 2017, portanto, os pombos começaram a se instalar sob a mesma (dado obtido a partir de entrevista, em 11 de março de 2021). Em 13 de março de 2020, uma reportagem do jornal $\mathrm{O}$ Livre intitulada "Em Vila Bela, ruínas da Igreja Matriz viram "poleiro" de pombos", constata a permanência das aves desde 2017. Ainda, segundo a reportagem, uma "moradora da cidade, [...] pontua que a antiga cobertura das ruínas, translúcidas em policarbonato, repelia os animais. Bastou a nova, com telhas que produzem sombra, para que eles se sentissem à vontade e ocupassem a área", declaração que indica que, embora as telhas tenham sido trocadas com a finalidade de proteger o bem, o efeito foi inesperado e danoso. Estudos especializados apontam que pombos domésticos vivem em locais com oferta de comida e condições favoráveis à sua permanência, com sombra e abrigo, cuja eliminação evita a presença dos animais (CEVS/RS, 2018; BENCKE, 2007). Registros fotográficos recentes permitem verificar que as aves se acomodam sobre as ruínas em suas inúmeras saliências e na estrutura da cobertura, onde há sombra (Figura 3).

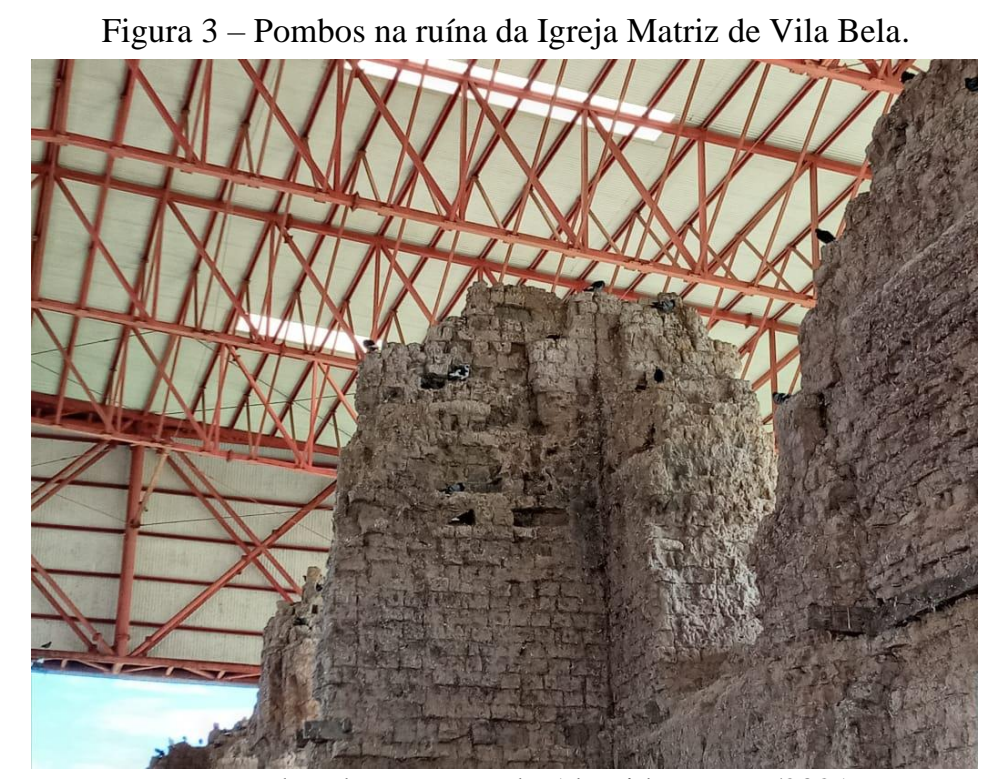

Fonte: Ednardo Marques de Almeida, março/2021.

Segundo relatado pelo Secretário de Meio Ambiente de Vila Bela, em 15 de março 2021, existe ainda outro fator que prejudica a conservação das ruínas e que está relacionado à cobertura: as "paredes estão se deteriorando, penso eu, que isso está ocorrendo por falta de umidade nas paredes devido a cobertura; o material adubo precisa ser umedecido". Esse aspecto deve ser investigado pois, se por um lado a cobertura protege das águas abundantes em período de chuvas, por outro, pode interferir no umedecimento natural, deixando as paredes mais vulneráveis à ação dos ventos, por exemplo, que causa desgastes. 


\section{c) Problemas tecnológicos}

COBERTURA DA RUÍNA: Nos períodos de chuva, a cobertura concentra e joga água em seis pontos ao redor da ruína, inclusive ao lado do piso de acesso ao seu interior (Figuras 4 e 5).

Figuras 4 e 5 - Canos de escoamento de água, acima na foto 4 e acúmulo de água na foto 5.
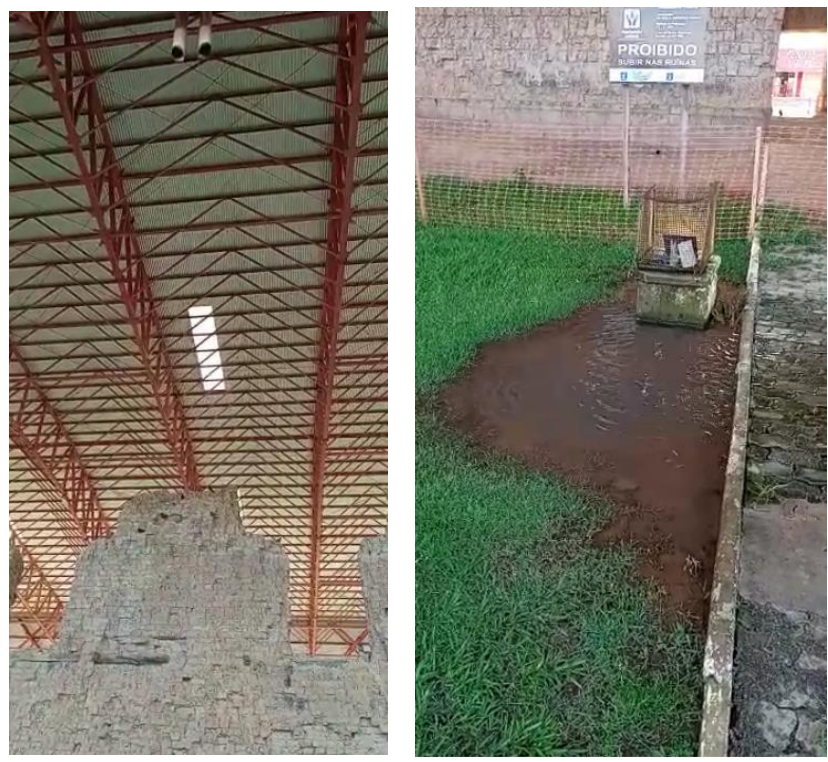

Fonte: Ednardo Marques de Almeida, abril/2021.

SISTEMA DE DRENAGEM URBANA: Segundo relatos, a falta de sistema de drenagem na cidade afeta também a ruína, pois água que cai dos telhados da cobertura se acumula ao redor do bem, sem encontrar rápido escoamento. Em 2017, foi elaborado o "Plano Municipal de Saneamento Básico: Vila Bela da Santíssima Trindade" (LIMA, MODESTO, MOURA, 2017, p. 195-202) onde estão registrados, da página 195 a 202, os problemas relativos à "falta ou ineficiência do sistema de drenagem" na cidade.

\section{d) Má utilização}

Durante a audiência, houve relatos sobre a má utilização das ruínas por pessoas que costumam frequentar a região do perímetro tombado da cidade de Vila Bela. Por estar mal iluminada e malcuidada, a ruína se transformou em local propício a utilizações inoportunas, como satisfação de necessidades fisiológicas, especialmente durante o período noturno. $\mathrm{O}$ acúmulo de sujeira e odores contribui para a degradação do bem, criando um círculo vicioso.

Em função da degradação causada pelos pombos, atualmente, as pessoas evitam se aproximar das ruínas, conforme relato registrado em entrevista, em 24 de março de 2021: "o que era para ser cartão postal atrativo, acaba afastando as pessoas, diminuiu, ninguém que ir lá porque tem medo dessa doença do pombo". O fato de não haver mais circulação de pessoas pelas ruínas e proximidades, favorece a apropriação indevida do espaço relatado anteriormente.

\section{e) Conflitos humanos}

Como já relatado, há conflitos que emergem dos diferentes pontos de vista que atuam em Vila Bela. Se, por um lado, para efetivar a preservação do patrimônio cultural, foram tomadas medidas pelos órgãos de preservação e outras instituições municipais, estaduais e federais, por outro, nem sempre essas medidas são bem recebidas pela população afroindígena 
local. Órgãos de preservação e instituições são entidades que, no geral, entendem os vestígios materiais de Vila Bela como representativos da memória do homem branco na fronteira Oeste. Porém, para a população local, o significado é mais amplo e representativo de sua formação identitária, de sua organização social e de sua independência em relação ao homem branco. Entendido como "espaço de liberdade", as intervenções nele realizadas pelas entidades citadas, são, por vezes, mal compreendidas e mal aceitas.

Esses conflitos podem acarretar prejuízos à conservação do patrimônio, devido ao sentimento de expropriação de lugares e bens. Se há uma ruptura, uma ausência de valores de pertencimento, por quais motivos se realizariam ações de conservação e preservação do patrimônio?

\subsubsection{Causas Naturais - Ações físicas}

\section{a) Chuvas}

As chuvas são um fator de degradação das edificações em terra crua (taipa, adobe) que não estejam protegidas por telhados e drenagens adequadas. Esse fator de degradação motivou a construção da cobertura que hoje se encontra sobre as ruínas. Efetivamente, foi uma medida que ajudou a protegê-la por muitos anos, como atesta o trecho da reportagem do Jornal Oeste (2011): "As ruínas estavam desabando muito rapidamente e, com a construção parou de se degradar, informou o superintendente regional do Iphan, [...]"

\section{b) Umidade do ar e Ventos}

Novamente se coloca a questão levantada pelo Secretário de Meio Ambiente de Vila Bela, sobre os fatores que podem estar acelerando o desgaste das estruturas de terra crua das ruínas, quais sejam: falta de umidade combinada à ação dos ventos. Tais fatores devem ser investigados por especialistas, para constatação, estimativa da importância da degradação relacionada e propositura de solução técnica.

\section{c) Acúmulo de sujeiras e odores}

Embora seja causada por intervenções inadequadas que acabaram servindo de abrigo aos pombos, o acúmulo das fezes desses animais no piso dos arredores da ruína e na própria ruína é uma causa natural de degradação e de risco à saúde pública. $\mathrm{O}$ mesmo se aplica às fezes e urina humanas.

\subsection{Causas dos Problemas das Deteriorações e Recomendações}

No Quadro 1, apresenta-se a síntese dos problemas anteriormente relatados e as recomendações para minimizar e/ou resolver seus efeitos, para facilitar a consulta. No Quadro 2 , foram listados os principais métodos para o controle da colônia de pombos, apontando seus aspectos positivos e negativos relativamente ao fato de a Ruína ser bem cultural protegido que deve ser tratado como tal. 
Quadro 1 - Causas dos Problemas das Deteriorações e Recomendações.

\begin{tabular}{|c|c|c|c|}
\hline \multicolumn{3}{|c|}{ CAUSAS DA DETERIORAÇÃO } & RECOMENDAÇÕES \\
\hline \multirow{15}{*}{$\begin{array}{c}\text { CAUSAS } \\
\text { HUMANAS }\end{array}$} & \multirow{4}{*}{$\begin{array}{c}\text { FALTA DE } \\
\text { MANUTENÇÃO }\end{array}$} & $\begin{array}{c}\text { - Cobertura e telhas translúcidas } \\
\text { provisórias. }\end{array}$ & \multirow{4}{*}{$\begin{array}{l}\text { VER PROPOSTAS (item } 3.4 \\
\text { deste trabalho). }\end{array}$} \\
\hline & & $\begin{array}{l}\text { - Não houve manutenção das telhas } \\
\text { translúcidas. }\end{array}$ & \\
\hline & & $\begin{array}{c}\text { - Instalação da colônia de pombos } \\
\text { sugere falta de controle dessa população } \\
\text { e falta de medidas de limpeza: a ser } \\
\text { verificado. }\end{array}$ & \\
\hline & & $\begin{array}{c}\text { - Sistema de Iluminação pública em } \\
\text { desuso e disfuncional, mas recentemente } \\
\text { reativada. }\end{array}$ & \\
\hline & \multirow{2}{*}{$\begin{array}{l}\text { INTERVENÇÕES } \\
\text { INADEQUADAS }\end{array}$} & $\begin{array}{l}\text { - Efeito inesperado da troca de telhas } \\
\text { translúcidas por telhas opacas: abrigo } \\
\text { para pombos e acúmulo das fezes dos } \\
\text { animais na ruína e em seus arredores. }\end{array}$ & $\begin{array}{l}\text { VER PROPOSTAS (item } 3.4 \\
\text { deste trabalho). }\end{array}$ \\
\hline & & $\begin{array}{c}\text { - Possível interferência da cobertura } \\
\text { sobre o ressecamento da terra crua, que } \\
\text { o vento pode estar ajudando a desgastar: } \\
\text { a verificar. }\end{array}$ & $\begin{array}{l}\text { Necessário estudo técnico } \\
\text { especializado. }\end{array}$ \\
\hline & \multirow[b]{2}{*}{$\begin{array}{l}\text { PROBLEMAS } \\
\text { TECNOLÓGICOS }\end{array}$} & $\begin{array}{l}\text { - Escoamento da água das chuvas da } \\
\text { cobertura em } 6 \text { pontos, formando poças. }\end{array}$ & $\begin{array}{c}\text { VER PROPOSTAS (item } 3.4 \\
\text { deste trabalho). }\end{array}$ \\
\hline & & $\begin{array}{c}\text { - Falta de sistema de drenagem } \\
\text { adequado: }\end{array}$ & $\begin{array}{c}\text { Verificar no Plano de } \\
\text { Saneamento Básico da } \\
\text { Prefeitura Municipal (LIMA, } \\
\text { MODESTO, MOURA,2017), } \\
\text { pág. 408, item 8.3.2: quais } \\
\text { medidas mitigadoras foram } \\
\text { realizadas. }\end{array}$ \\
\hline & \multirow{5}{*}{$\begin{array}{c}\text { MÁ } \\
\text { UTILIZAÇÃO }\end{array}$} & $\begin{array}{c}\text { - Utilização da ruína como banheiro } \\
\text { público com acúmulo de sujeira e } \\
\text { odores. }\end{array}$ & $\begin{array}{l}\text { Construção de banheiros } \\
\text { públicos nas proximidades. }\end{array}$ \\
\hline & & \multirow{4}{*}{$\begin{array}{c}\text { - Falta de iluminação adequada, fezes } \\
\text { de pombos, sujeiras e odores afastam } \\
\text { outras atividades positivas. }\end{array}$} & $\begin{array}{l}\text { Vigilância, em especial no } \\
\text { período noturno. }\end{array}$ \\
\hline & & & Iluminação pública adequada. \\
\hline & & & Manutenção periódica. \\
\hline & & & $\begin{array}{l}\text { Ações de educação } \\
\text { patrimonial e de assistência } \\
\text { social. }\end{array}$ \\
\hline & \multirow{2}{*}{$\begin{array}{l}\text { CONFLITOS } \\
\text { HUMANOS }\end{array}$} & $\begin{array}{c}\text { - Ações das instituições públicas } \\
\text { desconectadas dos anseios da população } \\
\text { local. }\end{array}$ & $\begin{array}{l}\text { - Sensibilização sobre os } \\
\text { anseios da população através } \\
\text { de capacitação voltada aos } \\
\text { servidores públicos de todas } \\
\text { as esferas envolvidas. }\end{array}$ \\
\hline & & $\begin{array}{l}\text { - Conhecimento superficial sobre as } \\
\text { instituições públicas e suas funções. }\end{array}$ & $\begin{array}{l}\text { - Sensibilização sobre as } \\
\text { funções das instituições } \\
\text { públicas através de educação } \\
\text { patrimonial voltadas a } \\
\text { população em geral. }\end{array}$ \\
\hline
\end{tabular}


Pelaes Mascaro, Luciana; Diagnóstico Técnico Preliminar da Ruína da Igreja Matriz de Vila Bela da Santíssima Trindade-MT e entorno. E\&S Engineering and Science, 2021, 10:2.

Quadro 1 - Causas dos Problemas das Deteriorações e Recomendações.

\begin{tabular}{|l|c|c|c|}
\hline CAUSAS & CHUVAS & $\begin{array}{c}\text { - São um fator de degradação das } \\
\text { edificações em terra crua (taipa, adobe) } \\
\text { que não estejam protegidas por telhados } \\
\text { e drenagens adequadas. }\end{array}$ & $\begin{array}{c}\text { Protegida contra esse fator pela } \\
\text { cobertura. }\end{array}$ \\
\cline { 2 - 4 } & $\begin{array}{c}\text { UMIDADE DO } \\
\text { AR E VENTOS }\end{array}$ & $\begin{array}{c}\text { - Possibilidade de falta de umidade } \\
\text { combinada à ação dos ventos. }\end{array}$ & $\begin{array}{c}\text { Necessário estudo técnico } \\
\text { especializado. }\end{array}$ \\
\cline { 2 - 4 } & $\begin{array}{c}\text { ACÚMULO DE } \\
\text { SUJEIRAS }\end{array}$ & $\begin{array}{c}\text { '- Acúmulo Fezes de pombos; acúmulo } \\
\text { de dejetos humanos e odores. }\end{array}$ & $\begin{array}{c}\text { Necessária limpeza e } \\
\text { manutenção; limpeza de fezes } \\
\text { de pombos sobre os adobes } \\
\text { deve ser realizada por equipe } \\
\text { técnica especializada. }\end{array}$ \\
\hline
\end{tabular}

Quadro 2 - Métodos e dispositivos para controle de Agente biológico: Pombo doméstico.

\begin{tabular}{|c|c|c|c|}
\hline $\begin{array}{l}\text { MÉTODOS E } \\
\text { DISPOSITIVOS }\end{array}$ & DETALHES & ASPECTOS POSITIVOS & ASPECTOS NEGATIVOS \\
\hline \multirow{4}{*}{$\begin{array}{l}\text { BARREIRA } \\
\text { FÍSICA E } \\
\text { ILUMINAÇÃO }\end{array}$} & Telas. & $\begin{array}{c}\text { Eficiente: impedem acesso aos } \\
\text { abrigos. }\end{array}$ & $\begin{array}{l}\text { Necessário analisar COMO deve } \\
\text { ser a instalação (nesse caso, não } \\
\text { pode fechar totalmente o espaço, } \\
\text { devendo ser instalada junto ao } \\
\text { telhado - ver foto xx). }\end{array}$ \\
\hline & $\begin{array}{l}\text { Telhas } \\
\text { translúcidas. }\end{array}$ & $\begin{array}{l}\text { Eficiente: mantém o local } \\
\text { iluminado, evitando que se } \\
\text { configure como abrigo. }\end{array}$ & $\begin{array}{l}\text { Custo: mais cara que a telha } \\
\text { opaca e requer trocas periódicas. }\end{array}$ \\
\hline & $\begin{array}{l}\text { Refletores } \\
\text { direcionados } \\
\text { com luzes } \\
\text { amarelas } \\
\text { (solar). }\end{array}$ & $\begin{array}{c}\text { Eficiente: mantém o local } \\
\text { iluminado, evitando que se } \\
\text { configure como abrigo / a } \\
\text { instalação pode ser combinada } \\
\text { com iluminação noturna, evitando } \\
\text { uso indevido por pessoas / } \\
\text { valoriza o bem. }\end{array}$ & $\begin{array}{c}\text { Custo: requer instalação, } \\
\text { manutenção e vigilância (para não } \\
\text { serem roubadas e/ou } \\
\text { vandalizadas). }\end{array}$ \\
\hline & $\begin{array}{l}\text { Espículas } \\
\text { (metálicas ou } \\
\text { plásticas). }\end{array}$ & Evitam o pouso das aves. & $\begin{array}{l}\text { Devem ser fixadas na superfície } \\
\text { do bem; no caso das ruínas, são } \\
\text { muitas superfícies utilizadas pelas } \\
\text { pombas: podem causar danos nas } \\
\text { paredes e interferência visual. }\end{array}$ \\
\hline \multirow{3}{*}{$\begin{array}{l}\text { DISPOSITIVO } \\
\text { DE CONTROLE } \\
\text { POPULACION } \\
\text { AL }\end{array}$} & Pombais. & $\begin{array}{l}\text { Concentram os animais onde é } \\
\text { possível fazer o manejo } \\
\text { (esterilização de indivíduos e } \\
\text { inviabilização dos ovos). }\end{array}$ & $\begin{array}{l}\text { Necessita um programa de } \\
\text { controle permanente } \\
\text { (manutenção); necessita } \\
\text { construção adequada / custo de } \\
\text { construção. }\end{array}$ \\
\hline & $\begin{array}{l}\text { Contraceptivos } \\
\text { (hormônio } \\
\text { ministrado } \\
\text { como ração). }\end{array}$ & $\begin{array}{l}\text { Resultados significativos e } \\
\text { duradouros a médio e longo prazo } \\
\text { na redução da população; sem } \\
\text { efeitos colaterais para outros } \\
\text { animais. }\end{array}$ & $\begin{array}{c}\text { Uso contínuo (compra e } \\
\text { distribuição da ração); produto } \\
\text { importado. }\end{array}$ \\
\hline & $\begin{array}{l}\text { Falcoaria } \\
\text { (treinamento e } \\
\text { uso de } \\
\text { predadores de } \\
\text { aves). }\end{array}$ & $\begin{array}{l}\text { Resultados significativos e } \\
\text { duradouros a médio e longo prazo } \\
\text { na redução da população / sem } \\
\text { impacto visual. }\end{array}$ & $\begin{array}{l}\text { Custo elevado / manutenção } \\
\text { permanente (cuidados com o } \\
\text { falcão/gavião) / contratação de } \\
\text { empresa especializada. }\end{array}$ \\
\hline
\end{tabular}


Pelaes Mascaro, Luciana; Diagnóstico Técnico Preliminar da Ruína da Igreja Matriz de Vila Bela da Santíssima Trindade-MT e entorno. E\&S Engineering and Science, 2021, 10:2.

Quadro 2 - Métodos e dispositivos para controle de Agente biológico: Pombo doméstico.

\begin{tabular}{|c|c|c|c|}
\hline \multirow[t]{4}{*}{$\begin{array}{c}\text { ELEMENTOS } \\
\text { DESAGRADÁVEIS } \\
\text { AOS ANIMAIS }\end{array}$} & $\begin{array}{l}\text { "Hipnose" através de } \\
\text { painéis com desenhos } \\
\text { circulares coloridos. }\end{array}$ & $\begin{array}{c}\text { Fáceis de serem } \\
\text { instalados / baixo custo / } \\
\text { permitem ações de } \\
\text { educação patrimonial } \\
\text { combinadas e } \\
\text { envolvimento da } \\
\text { população. }\end{array}$ & $\begin{array}{l}\text { Funcionam por algum } \\
\text { tempo e em locais } \\
\text { específicos / podem } \\
\text { interferir na visualização } \\
\text { do bem tombado. }\end{array}$ \\
\hline & $\begin{array}{l}\text { Elementos refletores de } \\
\text { luz (balões prateados; } \\
\text { CD’s). }\end{array}$ & $\begin{array}{c}\text { Fáceis de serem } \\
\text { instalados / baixo custo } \\
\text { /permitem ações de } \\
\text { educação patrimonial } \\
\text { combinadas e } \\
\text { envolvimento da } \\
\text { população. }\end{array}$ & $\begin{array}{l}\text { Funcionam por algum } \\
\text { tempo e em locais } \\
\text { específicos / podem } \\
\text { interferir na visualização } \\
\text { do bem tombado. }\end{array}$ \\
\hline & Espantalhos e móbiles. & $\begin{array}{c}\text { Fáceis de serem } \\
\text { instalados / baixo custo } \\
\text { /permitem ações de } \\
\text { educação patrimonial } \\
\text { combinadas e } \\
\text { envolvimento da } \\
\text { população. }\end{array}$ & $\begin{array}{l}\text { Funcionam por algum } \\
\text { tempo e em locais } \\
\text { específicos / podem } \\
\text { interferir na visualização } \\
\text { do bem tombado. }\end{array}$ \\
\hline & $\begin{array}{l}\text { Géis e pastilhas } \\
\text { repelentes. }\end{array}$ & Impacto visual pequeno. & $\begin{array}{l}\text { Reaplicação periódica em } \\
\text { todas as superfícies de } \\
\text { pouso / não há } \\
\text { informações sobre } \\
\text { possíveis danos a partir } \\
\text { de reações químicas com } \\
\text { as ruínas. } \\
\end{array}$ \\
\hline $\begin{array}{l}\text { DISPOSITIVOS } \\
\text { ELÉTRICOS }\end{array}$ & Faixas eletrificadas. & $\begin{array}{l}\text { Menor interferência } \\
\text { visual. }\end{array}$ & $\begin{array}{l}\text { Devem ser fixadas na } \\
\text { superfície do bem; no } \\
\text { caso das ruínas, são } \\
\text { muitas superfícies } \\
\text { utilizadas pelas pombas: } \\
\text { podem causar danos nas } \\
\text { paredes. }\end{array}$ \\
\hline \multirow[t]{2}{*}{ SONS } & $\begin{array}{c}\text { Gritos, piados e cantos } \\
\text { dos predadores através de } \\
\text { megafones. }\end{array}$ & $\begin{array}{l}\text { Mínima interferência } \\
\text { visual / baixo custo. }\end{array}$ & $\begin{array}{c}\text { Funcionam por algum } \\
\text { tempo / custo: requer } \\
\text { instalação do } \\
\text { equipamento de som, } \\
\text { manutenção e vigilância } \\
\text { (para não serem roubadas } \\
\text { e/ou vandalizadas). }\end{array}$ \\
\hline & Emissão de ultrassons. & $\begin{array}{l}\text { Mínima interferência } \\
\text { visual / baixo custo. }\end{array}$ & $\begin{array}{l}\text { Pode incomodar e fazer } \\
\text { sofrer outros animais } \\
\text { (cães ou eventuais } \\
\text { predadores naturais dos } \\
\text { pombos). }\end{array}$ \\
\hline
\end{tabular}

\subsection{Propostas}

\subsubsection{Cobertura de Proteção}

Opção 1: Retirada da Cobertura 
A possibilidade de retirada completa da cobertura existente deve ser considerada devido aos fatores:

i) o impacto na paisagem é inegável e é fato registrado em mais de um trabalho sobre arquitetura:

\begin{abstract}
"contrapor estruturas novas e antigas tem seus riscos, bem ilustrados pelo projeto de Ernesto Gabiatto Neto para a cobertura de proteção das ruínas (...) são quatro torres que dominam a histórica cidade, superando em muito a altura e o alcance visual das antecedentes" [as torres da igreja que não mais existem] (...). As alturas desencontradas desses pilares, conferem-lhe um caráter inacabado, competindo com a incompletude das ruinas" (CASTOR, 2013, p.382).
\end{abstract}

Segundo Freixo (2017, p. 133)

\begin{abstract}
"o efeito da cobertura em estrutura metálica vermelha, apesar da cobertura translúcida, compete com a beleza das formas arruinadas dos vestígios da Igreja, causando estranheza e desconforto ao observador, não sendo unanimidade entre a comunidade, que apesar de concordar com a necessidade da cobertura, questionou a intervenção",
\end{abstract}

Ainda, de acordo com Rodrigues (2017, p.148) "no Brasil, a cobertura é um elemento de extremo impacto no caso da Igreja Matriz de Vila Bela (...). A cobertura é estritamente funcional (...). Trata-se de uma intervenção que contrasta com as ruínas”. E, ainda, segundo a própria população, como apuramos em questionários realizados em março e abril de 2021, "o que mais ouço sobre a cobertura é que ela chama mais atenção do que as Ruínas. Muitos se preocupam com a paisagem das Ruínas, por ser o cartão postal da cidade. Reclamações de que o projeto de cobertura é inacabado". Portanto, verifica-se que em vários pontos do país, a cobertura é vista como equívoco e como elemento que atrapalha a paisagem, além de não ser bem aceito pela população local.

ii) as condições atuais da cobertura causam mais danos que benefícios. Embora se reconheça o importante papel da cobertura existente que protegeu a ruína das chuvas durante alguns anos, como informado pelo Secretário Municipal de Cultura - "alguns concordam que a cobertura ajudou na manutenção do prédio" -, esse aspecto positivo pode ser questionado atualmente. Assim, é necessário considerar a possibilidade de retirada da cobertura, com base nos custos, possíveis recursos e benefícios. Caso essa seja a decisão tomada, é absolutamente necessário que outra cobertura se construa em seu lugar. Outro projeto de cobertura deve considerar época de retirada e construção para evitar exposição da ruína em período de chuvas; deve ter caráter definitivo; deve ser adequada à paisagem; e, deve considerar a contribuição da população local para o projeto.

ASPECTOS POSITIVOS: a) impacto positivo junto à população local e imagem positiva das ações de conservação da ruína em nível nacional; b) recuperação das qualidades da paisagem original; c) valorização da ruína; d) eliminação dos problemas atuais.

ASPECTOS NEGATIVOS: a) necessidade de análise de custos de demolição e construção; b) necessidade de recursos para demolição e construção; c) necessidade de articulação com construção da nova cobertura, para que a ruína não fique exposta às chuvas.

\title{
Opção 2: Troca das Telhas da Cobertura
}

Caso não se opte pela retirada completa da cobertura da ruína, a troca das telhas opacas por telhas translúcidas se coloca como a solução mais adequada para resolver um dos mais graves problemas encontrados no local: a colônia de pombos. 
Embora a cobertura atual tenha muitas características que prejudicam a fruição do bem, o fato de sua cobertura original ser composta por telhas translúcidas era positivo em dois aspectos:

i) Materiais translúcidos ou transparentes, em geral, são bem aceitos em intervenções em bens culturais protegidos por causa de suas qualidades: leveza, acesso visual, pouco impacto visual. $\mathrm{O}$ que não significa que sempre será o material mais adequado. No caso da cobertura da ruína de Vila Bela, conferia-lhe mais leveza visual, pois estava sempre luminosa (Figuras 6 e 7);

ii) Empiricamente, como mencionado nas entrevistas, se constatou que as telhas translúcidas não agradavam aos pombos. Esse dado, somado às informações da Secretaria Estadual de Saúde/RS (2018) e Bencke (2007) - de que os pombos têm preferência por lugares altos e sombreados -, reforça a observação de que a troca das telhas translúcidas por opacas transformou a cobertura em abrigo para pombos, um efeito inesperado. Além disso, em contato telefônico com o médico veterinário da Vigilância em Saúde Ambiental da Secretaria de Estado de Saúde de Mato Grosso, em março de 2021, foi sugerida a eliminação de abrigo e comida para os pombos.

Esta opção deve vir contemplar os seguintes itens:

- Troca das telhas opacas por telhas translúcidas de polipropileno, fibra de vidro ou policarbonato (avaliar custo x durabilidade);

- Retirada de ninhos e limpeza da estrutura, ruínas e piso (fezes e penas) de acordo com orientações técnicas para evitar danos ao bem e contaminação; ruínas, etc.

- Comunicação visual para orientação dos visitantes: não alimentar aves, não tocar nas

Figuras 6 e 7 - Cobertura com telhas opacas e com telhas translúcidas.
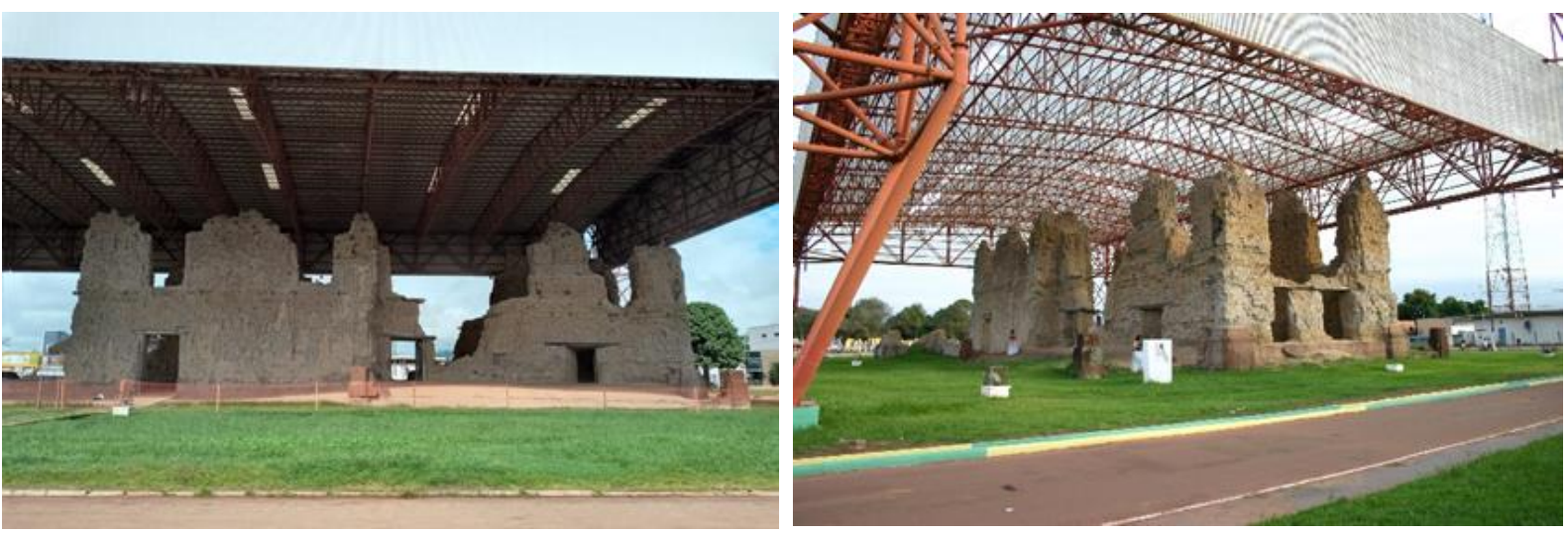

Fonte: foto à esquerda, Ednardo Marques de Almeida, março/2021; foto à direita Luciana Mascaro, maio/2014.

ASPECTOS POSITIVOS: a) eliminação da causa da instalação da colônia de pombos nas ruínas; b) recuperação de certa leveza para a cobertura de proteção e consequente suavização do impacto da mesma na paisagem; c) menor custo que a retirada e construção de nova cobertura.

ASPECTOS NEGATIVOS: a) necessidade de recursos, mesmo que menores.

\section{Opção 3: Medidas Paliativas}

Caso nenhuma das opções anteriores seja aceita, resta a adoção de medidas paliativas para afastar e controlar a população de pombos. Essas medidas, detalhadas no quadro 3, requerem constante atenção. Caso não haja vigilância, manutenção e limpeza permanentes, as pombas provavelmente voltarão, pois encontram nesse ambiente, condições ideais de vida: altura, sombra, alimento. 
No caso da opção pelas medidas paliativas, a parte interna da estrutura superior da cobertura metálica, abaixo das vigas que suportam as telhas, deverá ser protegida como uma tela. Essa tela não impedirá que os pombos permaneçam sobre a própria ruína. É mais um elemento visual a ser acrescentado e pode interferir ainda mais no visual do conjunto da cobertura: estrutura metálica, telhas opacas, tela de proteção.

ASPECTOS POSITIVOS: a) baixo custo.

ASPECTOS NEGATIVOS: a) permanecerá uma situação de conservação e proteção do patrimônio insatisfatória e ineficiente em vários aspectos; b) solução paliativa, que dependerá de vigilância, manutenção e limpeza permanentes; caso contrário, haverá risco de reinstalação dos pombos; c) não age na causa do problema e não elimina as condições ideais de vida dos pombos; d) requer a instalação de tela de proteção na estrutura superior da cobertura; requer recursos, mesmo que menores.

\section{Opção 4: Cercamento total da cobertura}

O cercamento total da cobertura de proteção foi aqui considerada pois apareceu como opção em outras ocasiões. Embora seja a opção mais imediata, talvez seja a menos adequada sob vários aspectos, quais sejam:

i) O impacto visual de uma tela que envolve toda a ruína é inevitável, mesmo que se trate de tela leve: haverá um elemento entre a ruína e o observador;

ii) O impacto da cobertura de proteção na paisagem será intensificado;

iii) Será de difícil aceitação por parte da população local que, como já foi explanado, entende o espaço em questão como "espaço de liberdade" e verá a tela como mais um elemento que a separa de sua herança histórica e cultural. Além disso, pode aprofundar a resistência e a falta de entendimento mútuo entre população e instituições;

iv) Tornará uma condição provisória e inadequada em uma condição cada vez mais permanente.

ASPECTOS POSITIVOS: a) baixo custo.

ASPECTOS NEGATIVOS: a) impacto visual e na paisagem; b) barreira física entre a população e sua herança histórica e cultural; c) aprofundamento do conflito população/instituições; d) não resolve as causas dos problemas.

O Quadro 3 apresenta o resumo das opções sugeridas para resolução de problemas, patologias e degradações ligadas a Ruína propriamente dita e aos seus arredores. 
Quadro 3 - Propostas para as Ruínas e arredores.

\begin{tabular}{|c|c|c|c|}
\hline & $\begin{array}{c}\text { AÇÕES } \\
\text { PROPOSTAS }\end{array}$ & ASPECTOS POSITIVOS & ASPECTOS NEGATIVOS \\
\hline \multirow[t]{4}{*}{$\begin{array}{c}5.1 . \\
\text { Cobertura de } \\
\text { Proteção }\end{array}$} & $\begin{array}{c}\text { 5.1.1. Opção: } \\
\text { 1 Retirada da } \\
\text { Cobertura. }\end{array}$ & $\begin{array}{c}\text { a) Impacto positivo junto à população } \\
\text { local e imagem positiva das ações de } \\
\text { conservação da ruína em nível } \\
\text { nacional; } \\
\text { b) Recuperação das qualidades da } \\
\text { paisagem original; } \\
\text { c) Valorização da ruína; a UFMT pode } \\
\text { contribuir com o desenvolvimento de } \\
\text { um novo projeto de cobertura de } \\
\text { proteção. } \\
\text { d) Eliminação das causas dos } \\
\text { problemas atuais. }\end{array}$ & $\begin{array}{l}\text { a) Necessidade de análise de } \\
\text { custos de demolição e construção; } \\
\text { b) Alto custo; } \\
\text { c) Necessidade de articulação } \\
\text { com construção da nova } \\
\text { cobertura, para que a ruína não } \\
\text { fique exposta às chuvas. }\end{array}$ \\
\hline & $\begin{array}{l}\text { 5.1.2. Opção } \\
\text { 2: Troca das } \\
\text { Telhas da } \\
\text { Cobertura. }\end{array}$ & $\begin{array}{l}\text { a) Eliminação da causa da instalação da } \\
\text { colônia de pombos nas ruínas; } \\
\text { b) Recuperação de certa leveza para a } \\
\text { cobertura de proteção e consequente } \\
\text { suavização do impacto da mesma na } \\
\text { paisagem; } \\
\text { c) Menor custo que a retirada e } \\
\text { construção de nova cobertura. }\end{array}$ & a) Custos intermediários. \\
\hline & $\begin{array}{l}\text { 5.1.3. Opção } \\
\text { 3: Medidas } \\
\text { Paliativas. }\end{array}$ & a) Baixo custo. & $\begin{array}{l}\text { a) Permanência da situação de } \\
\text { conservação e proteção do } \\
\text { patrimônio insatisfatória; } \\
\text { b) Solução paliativa, que } \\
\text { dependerá de vigilância, } \\
\text { manutenção e limpeza } \\
\text { permanentes; risco de reinstalação } \\
\text { dos pombos; } \\
\text { c) Não age na causa do problema } \\
\text { e não elimina as condições ideais } \\
\text { de vida dos pombos; } \\
\text { d) Requer a instalação de tela de } \\
\text { proteção na estrutura superior da } \\
\text { cobertura; } \\
\text { e) Requer recursos, mesmo que } \\
\text { menores. }\end{array}$ \\
\hline & $\begin{array}{l}\text { 5.1.4. Opção } \\
\text { 4: Cercamento } \\
\text { total da } \\
\text { cobertura. }\end{array}$ & a) Baixo custo. & $\begin{array}{l}\text { a) Impacto visual e na paisagem; } \\
\text { b) Barreira física entre a } \\
\text { população e sua herança histórica } \\
\text { e cultural; } \\
\text { c) Aprofundamento do conflito } \\
\text { população/instituições; } \\
\text { d) Não resolve as causas dos } \\
\text { problemas. }\end{array}$ \\
\hline
\end{tabular}


Quadro 3 - Propostas para as Ruínas e arredores.

\begin{tabular}{|c|c|c|c|}
\hline \multirow[t]{7}{*}{$\begin{array}{l}5.2 . \\
\text { Conservação } \\
\text { da Ruína }\end{array}$} & $\begin{array}{l}\text { 5.2.1. Sistema } \\
\text { de Drenagem. }\end{array}$ & $\begin{array}{l}\text { a) Melhoria do sistema de } \\
\text { drenagem e menor risco para o } \\
\text { patrimônio cultural. }\end{array}$ & $\begin{array}{l}\text { a) Custos (podem ser altos, } \\
\text { intermediários ou baixos). }\end{array}$ \\
\hline & $\begin{array}{l}\text { 5.2.2. Sistema } \\
\text { de Iluminação } \\
\text { Pública. }\end{array}$ & $\begin{array}{l}\text { a) Melhoria da segurança, do uso e da } \\
\text { conservação da ruína. } \\
\text { b) Baixo custo. }\end{array}$ & - \\
\hline & $\begin{array}{l}\text { 5.2.3. Estudos } \\
\text { Técnicos } \\
\text { Especializados. }\end{array}$ & $\begin{array}{l}\text { a) Perpetuação da ruína. } \\
\text { b) Impede danificação durante } \\
\text { processo de limpeza. } \\
\text { c) Indicação de como agir } \\
\text { relativamente à umidade e erosão } \\
\text { eólica. }\end{array}$ & $\begin{array}{l}\text { a) Custos (podem ser } \\
\text { intermediários ou baixos). }\end{array}$ \\
\hline & $\begin{array}{l}\text { 5.2.4. } \\
\text { Vigilância e } \\
\text { Assistência }\end{array}$ & $\begin{array}{l}\text { a) Melhoria da segurança, do uso e da } \\
\text { conservação da ruína. } \\
\text { b) Baixo custo. }\end{array}$ & - \\
\hline & & $\begin{array}{l}\text { a) Melhoria da segurança, do uso e da } \\
\text { conservação da ruína. } \\
\text { b) Baixo custo. }\end{array}$ & - \\
\hline & $\begin{array}{l}\text { 5.2.5. } \\
\text { Construção de } \\
\text { Banheiros } \\
\text { Públicos. }\end{array}$ & $\begin{array}{l}\text { a) Melhoria da higiene, do uso e da } \\
\text { conservação da ruína. } \\
\text { b) Maior conforto em ocasião de } \\
\text { festas para a população local e os } \\
\text { turistas. }\end{array}$ & a) Custo intermediário. \\
\hline & $\begin{array}{c}\text { 5.2.6. } \\
\text { Educação } \\
\text { Patrimonial. }\end{array}$ & $\begin{array}{l}\text { a) Melhoria da conservação da ruína. } \\
\text { b) Minimização de conflitos } \\
\text { humanos. } \\
\text { c) Protagonismo da população local } \\
\text { no processo de conservação do } \\
\text { patrimônio. } \\
\text { d) Baixo custo. }\end{array}$ & - \\
\hline
\end{tabular}

\section{CONSIDERAÇÕES FINAIS}

Do ponto de vista da conservação e do significado dos bens patrimoniais protegidos por tombamento, a realização deste diagnóstico técnico, ainda que preliminar, mostrou é imprescindível questionar sobre o que, de fato, eles evocam na atualmente. Sobre a ruína da Matriz de Vila Bela, sua cobertura de proteção metálica e seu entorno, o que se verifica é um processo de degradação que se instala e não a evocação de um passado cultural e material que deve ser rememorado, conservado e mantido para as próximas gerações. Assim, cabe retomar a questão colocada por Rodrigues (2013) e refletir sobre o que, hoje, significa a ruína de Vila Bela e seu entorno, "um passado distante consumido pelas marcas do tempo ou um recente histórico de abandono?"

No que diz respeito a metodologia para diagnóstico de bens tombados, este trabalho pode servir como referência, especialmente, no aspecto da relação do patrimônio material com usos e significados atuais. Além disso, evidencia que é relevante considerar as diversas naturezas das causas de danos para estruturar a análise; assim, foi necessário sistematizar e elencar causas humanas, causas naturais e suas subclassificações descritas. Destaca-se também a importância de condensar tais informações em quadros a fim de tornar a análise mais direta para quem dela fará uso. 
No que diz respeito aos aspectos técnicos, este trabalho registra o diagnóstico do atual estado de conservação da ruína e de seu entorno e indicou ações que podem ser tomadas. Dentre elas, é necessário avaliar a cobertura da ruína para decidir se deve ser retirada e substituída por outra, mais adequada sob os vários aspectos citados, ou, se deve ter suas telhas opacas trocadas por translúcidas, ou ainda, se apenas se deve tentar controlar a colônia de pombos lançando mão dos métodos e dispositivos citados. Essa decisão será também pautada na disponibilidade de recursos. A opção de simplesmente cercar completamente a ruína com tela parece ser a mais simples, porém, sem dúvida, é a mais equivocada visto que se trata de apartar a população local de sua própria herança patrimonial, o que pode aprofundar ainda mais os conflitos entre instituições e população. É preciso também considerar que é fundamental contratar especialistas em conservação e preservação do patrimônio para que aconselhem sobre como realizar a limpeza das paredes de adobe, sobre as quais se acumulam fezes de pombos, sem causar danos a essas paredes. Além disso, medidas para melhorar o sistema de drenagem da cidade devem ser tomadas, retomando o Plano Municipal de Saneamento Básico (LIMA, MODESTO, MOURA 2017). Igualmente, medidas para implementar um sistema de iluminação eficiente e para inibir a má utilização do espaço da ruína e seus arredores devem ser postas em prática. Finalmente, ações de assistência social e educação patrimonial, para a população local e para os servidores das instituições envolvidas, devem ser realizadas.

Finalmente, visto as condições gerais do local e da ruína, foi avaliado que decisões e medidas devem ser tomadas tão rápido quanto possível. Trata-se da responsabilidade conter a instalação de um processo de degradação cada vez mais difícil de reverter sobre o patrimônio cultural vilabelense, de importância local e nacional e com potencialidades diversas, inclusive para a economia, o turismo e a conservação do patrimônio e da memória.

\section{REFERÊNCIAS}

BARROS, L. Em Vila Bela, ruínas da Igreja Matriz viram "poleiro" de pombos. O Livre, Cuiabá, 13 de março de 2020. Disponível em: https://olivre.com.br/em-vila-bela-ruinas-daigreja-matriz-viram-poleiro-de-pombos . Acesso em 10 mar. 2021.

BENCKE, G. A. Pombos domésticos: Sugestões para o controle em Escolas Públicas Estaduais de Porto Alegre. Fundação Zoobotânica do Rio Grande do Sul. Porto Alegre, 2007.

CASTOR, R. S. Arquitetura Moderna em Mato Grosso: diálogos, contrastes e conflitos. Tese (doutorado). FAUUSP. São Paulo, 2013.

FACCHINETTO, J. Vila Bela Arquitetura, cultura e tradição negra cultivadas há 252 anos. In: I SEMINÁRIO ARTE E CIDADE - Salvador, maio de 2006. PPG-AU - Faculdade de Arquitetura / PPG-AV - Escola de Belas Artes / PPG-LL - Instituto de Letras, UFBA.

FINAGEIV, B. et al. Obras de Emergência nas Ruínas da Igreja Matriz e no Palácio dos Capitães Generais em Vila Bela da Santíssima Trindade - Mato Grosso. SPHAN, Fundação Nacional PróMemória, 8a . Diretoria Regional, 1984. (documento integrante do processo de tombamento estadual)

FREIXO, G. M. Projeto de revitalização nas ruínas do Mirante das Lendas, Teresópolis, Rio de Janeiro: reintegração de lacunas em painéis azulejares. Dissertação (mestrado). Universidade Federal do Rio de Janeiro, Faculdade de Arquitetura e Urbanismo, Programa de Pós-Graduação em Arquitetura, 2017. 
JORNAL OESTE. Cobertura das ruínas da Igreja Matriz de Vila Bela está se deteriorando. 14/08/2011. Disponível em: http://www.jornaloeste.com.br/noticias/exibir.asp?id=17588\&noticia=cobertura_das_ruinas_d a_igreja_matriz_de_vila_bela_esta_se_deteriorando. Acesso em: 15 mar. 2021.

LIMA, E. B. N. R., MODESTO FILHO, P., MOURA, R. M. P. (org.). Plano Municipal de Saneamento Básico: Vila Bela da Santíssima Trindade-MT. Cuiabá, MT : EdUFMT, 2017.

MigliaCiO, M. C. (org.). Complexo Arqueológico Histórico Arraial de São Francisco Xavier: instrução do processo de tombamento, IPHAN. Cuiabá, MT : Entrelinhas, 2011.

RODRIGUES, A. R. Ruína e patrimônio cultural no Brasil. Tese (doutorado). FAUUSP. São Paulo, 2017.

RODRIGUES, A. R. Ruínas do Abandono e sua Significação: o Caso do Sítio Mirim-São Paulo. In: ANAIS DO ARQUIMEMÓRIA 4, Salvador, Bahia, 14 a 17 de maio de 2013.

SECRETARIA ESTADUAL DA SAÚDE. Centro Estadual de Vigilância em Saúde. Guia de manejo e Controle de pombas-domésticas (Columba livia) em áreas urbanas. Org. André Alberto Witt. Porto Alegre: CEVS/RS, 2018. Disponível em: https://cevsadmin.rs.gov.br/upload/arquivos/201909/24082759-2018-guia-pombas.pdf Acesso em 10 mar. 2021.

SECRETARIA DE ESTADO DE CULTURA, Coordenadoria de Patrimônio Cultural, Bens tombados. Processo de Tombamento Estadual, Vila Bela da Santíssima Trindade. Pasta 2. Parecer no. 24, 10/12/2002. Cuiabá, MT, 1984.

VITAL, A. V.; HOCHMAN, G. . Da malária e da 'corrupção': medicina e saberes locais no noroeste do Brasil (Comissão Rondon, 1907-1915). BOLETIM DO MUSEU PARAENSE EMÍLIO GOELDI. CIÊNCIAS HUMANAS, v. 8, p. 77-94, 2013. 